\title{
A CSR ISMERTSÉGE ÉS MEGJELENÉSE A FOGYASZTÓI DÖNTÉSEKBEN
}

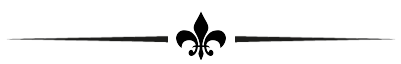

\section{AWARENESS AND EFFECT OF CSR ON CONSUMER DECISIONS}

\author{
.a. \\ ${ }^{1}$ CSAPÓNÉ RISKó, Tünde \\ 2PÉNTEK, Ádám \\ ${ }^{3}$ WIWCZAROSKI, TrOY \\ 10 \\ ${ }^{1}$ Debreceni Egyetem, Gazdaságtudományi Kar, Marketing és Kereskedelem Intézet \\ (University of Debrecen, Faculty of Economics and Business, Institute of Marketing and Commerce) \\ ${ }^{2}$ Debreceni Egyetem, Gazdaságtudományi Kar, Alkalmazott Informatika és Logisztika Intézet \\ (University of Debrecen, Faculty of Economics and Business, Institute of Applied Informatics and Logistics) \\ ${ }^{3}$ Debreceni Egyetem, Gazdaságtudományi Kar, Gazdasági Szaknyelvi Kommunikációs Intézet \\ (University of Debrecen, Faculty of Economics and Business, Institute of Economic Languages and Communication Studies) \\ e-mail: risko.tunde@econ.unideb.hu
}

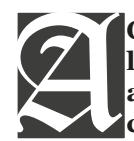

Corporate social responsibility (CSR) is a common topic, both at national and international levels. Profit maximisation is essential for companies, but they should not forget the social and environmental impacts of their activities. The question of sustainability is also a common topic requiring examination. The future of the Earth, our natural resources and the generations that will come after us also impact on the responsibilities of companies. For many companies, this kind of responsibility is natural and they take such CSR and sustainable steps that are worth following. From modern society, there is a high expectation and even strong pressure on companies to conduct responsible business practice. The number of responsible companies is increasing due to this pressure. What do we mean by CSR? What sorts of activities and steps are covered by CSR? What are the motivators of the CSR strategies, CSR activities of companies? What are their reasons? Many researchers investigate the motivators of CSR. From them, opinion on the company, image of the company, "consumers will prefer us", are among the most frequent ones. However, are the CSR actions of companies appreciated by consumers? The results of many researchers demonstrate that they are not appreciated. In general, responsible business practise is a high expectation from consumers, but when purchasing a product, this aspect is one of the least important factors. The aim of this paper is to collect some of the most relevant research findings on CSR, to introduce the informedness of Hungarian respondents on CSR in general, to find out the main influencing factors of their purchasing decisions, and also find correlations between the received results and the demographic variables based on our primary research. Our results support the present practice in terms of the definition of CSR. Almost all the listed alternatives are strongly associated with CSR by the respondents. The highest average received for the "creating workplaces, employment" alternative indicates the importance of this activity. Regarding the different factors influencing purchasing decision, our results underline the importance of price and price value ratio. This research finding is in line with other research findings, which shows that CSR actions of companies, responsible business practice is not the number one influencing factor of actual consumer decision.

KuLCSSZAVAK: vállalatok társadalmi felelősségvállalása, tudatos fogyasztás, CSR tevékenységek, fogyasztói döntés
KEYWORDS: corporate social responsibility, conscious consumption, CSR actions, consumer decision

\section{BeVEZETÉS - INTRODUCTION}

A vállalatok értékeinek és etikájának visszatükröződése kapcsán a vállalatok társadalmi fele- lősségvállalása (CSR) igen nagy kutatási figyelmet kapott az elmúlt évtizedben (POMERING és DOLNICAR, 2008). De mit is jelent a CSR?

Nem számít jó jelnek, amikor a szakma képviselői nem tudnak egyetérteni már az 
elnevezésben sem: vállalati felelősségvállalás (CR), fenntarthatóság, vállalatok társadalmi felelősségvállalása (CSR), fenntartható fejlődés, vállalatok elszámoltathatósága, közös értékteremtés (CSV), vállalati polgárság és társadalmi felelősségvállalás. Ezek mind elnevezések, de értelmezésük és használatuk laza. A CSR több, mint pusztán jótékonykodás. A CSR megváltoztatja az üzleti gyakorlatot, maximalizálja a vállalat társadalmi hasznát, miközben minimalizálja a kockázatokat és költségeket, továbbá üzleti és márkaértéket épít (EPSTEINREEVES, 2011).

A számos CSR definíciónak köszönhetően tanulságos lehet a közös vonások keresése. Különböző definíciókat vizsgálva, BUCHHOLTZ (1991) in SCHWARTZ és SAIIA (2012) megállapítja, hogy öt kulcselem azonos a legtöbb CSR definícióban:

- A vállalatok rendelkeznek felelősséggel, ami túlmutat a termékek és szolgáltatások nyereséges előállításán.

- Ez a felelősség magában foglalja fontos társadalmi problémák megoldását, különösképpen azokét, melyek létrejöttéért a vállalat felelős.
- A vállalatoknak tágabb érintetti köre van, mint pusztán csak a részvényesek.

- A vállalatoknak hatásai vannak, melyek túlmutatnak az egyszerü piaci tranzakciókon.

- A vállalatok szélesebb körben szolgálnak emberi értékeket, mint pusztán üzleti értékeket.

Nem csak a CSR koncepciója és definíciója tárgya különféle vitáknak. Az akadémiai és az üzleti szféra folyamatosan vitázik a CSR költségeiről és hozadékairól: érdemes invesztálni CSR tevékenységekbe, megéri társadalmilag felelősnek lenni? Miért felelősek a vállalatok?

A CSR tevékenységek befolyásolhatják a fogyasztói attitúdöket. A fogyasztók attitűdjei formálják céljaikat és ezek hatással vannak magatartásukra. Vagyis a vállalatok CSR tevékenységei inspirálhatják a fogyasztókat, hogy változtassanak fogyasztói magatartásukon (pl. másik terméket válasszanak), hajlandóak legyenek többet fizetni felelős termékekért, vagy szándékosan büntessék azokat a vállalatokat, amelyek nem felelnek meg elvárásaiknak (NBS, 2015). Az 1. ábra a társadalmilag tudatos fogyasztás modelljét szemlélteti.

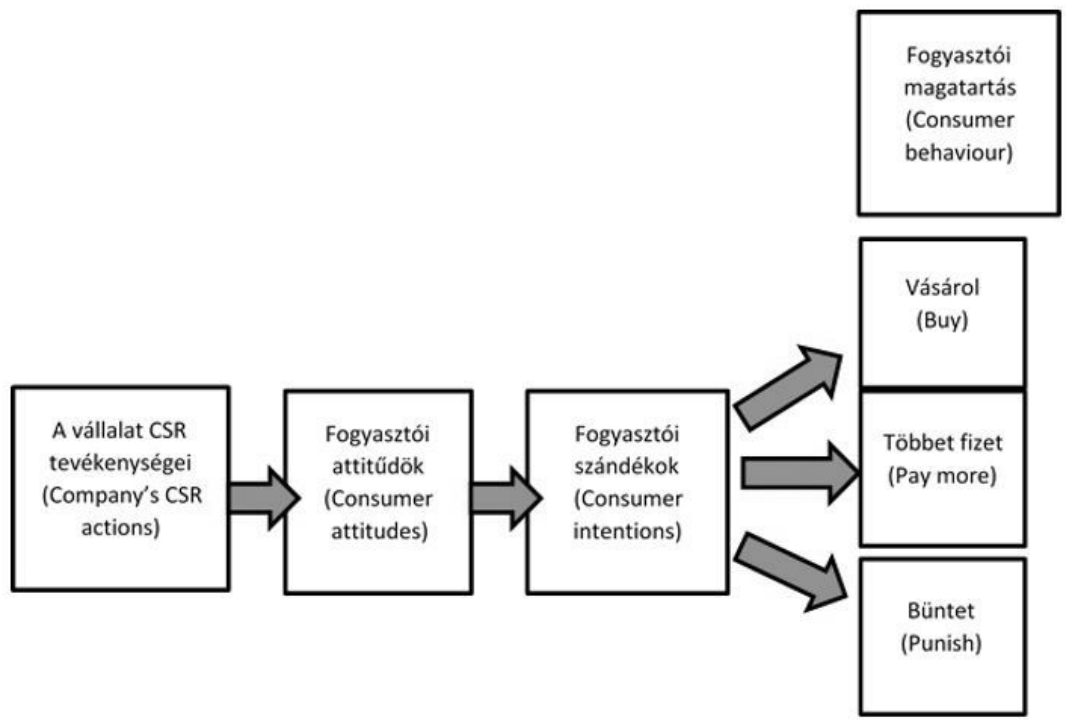

1. ÁBRA

A társadalmilag tudatos fogyasztás modellje

FIG. 1

Forrás (Source): NBS (2015)

(A Model of Socially Conscious Consumerism) 
KIM (2011) említi, hogy bár a tudományos kutatások egyre nagyobb hangsúlyt fektetnek a CSR vizsgálatára, korábbi kutatások meglehetősen vegyes eredményeket hoztak annak hatásaira vonatkozóan. Ilyen például a CSR hatása a vállalat pénzügyi teljesítményére vagy a fogyasztói válaszok, reakciók. A közös vonás a tudományos kutatások eredményei között az, hogy még mindig keveset tudunk arról, hogy hogyan és mikor múködnek a CSR kezdeményezések. A fogyasztók hajlamosak feltételezni, hogy egy vállalat felelős termékeket gyárt, ha erős CSR társul a vállalathoz.

LUKÁCS (2006) írja cikkében, hogy Margolis és Walsh kilencvenöt, a témával foglalkozó tanulmányt vizsgált meg és arra a megállapításra jutottak, hogy nyilvánvalóan pozitív kapcsolat feltételezhetô a vállalatok társadalmi és pénzügyi teljesítménye között. Akár független, akár függő változóként vizsgálták a társadalmi felelősségvállalás terén nyújtott teljesítményt, a legtöbb esetben pozitív kapcsolatot találtak a társadalmi és a pénzügyi teljesítmény között. Jóval kevesebb olyan tanulmány volt, amely negatív, illetve nem létező kapcsolatot állapított meg a két terület között.

DOANE (2005) kifejti a CSR négy mítoszát. Doane elméletének egyik figyelemreméltó része az etikus fogyasztáshoz kötődő mítoszok; nevezetesen, hogy a piac egyszerre tudja elősegíteni a rövid távú pénzügyi és a hosszú távú társadalmi hasznokat vagy az a tévhit, hogy az etikus fogyasztók majd rákényszerítik a vállalatokat a változásra. GYŐRI (2013) hozzáteszi, hogy a tudatos fogyasztók kinyilvánított preferenciái sokkal erősebbek a környezettudatos, egészséges vagy társadalmilag felelősen előállított termékek iránt, mint az valós vásárlói döntéseik esetében megfigyelhető. Még azokban az esetekben is, mikor a „felelős” termék olcsóbb, berögződött szokásaik miatt akkor is gyakran a másik terméket választják. ÖBERSEDER et al. (2011) hangsúlyozzák, hogy egy megoldatlan paradoxon, ami a vállalatok társadalmi felelősségvállalásának (CSR) szerepét illeti a fogyasztói magatartásban: a fogyasztók egyrészt egyre több CSR információt igényelnek a vállalatoktól, másrészt kutatásaik jelentős szakadékot jeleznek a fogyasztók látszólagos CSR érdeklődése és a CSR alacsony szerepe között a fogyasztói döntésben.
ÖBERSEDER et al. (2011) kutatási eredménye is azt mutatja, hogy a CSR nincs a fogyasztói bevásárló listák élén (hivatkoznak még további kutatási eredményekre is: BECKMANN et al. (2001); BELK et al. (2005); BRAY et al. (2011); LICHTENSTEIN et al. (2004); MOHR et al. (2001). POMERING és DOLNICAR (2009) kutatási eredményei bankvezetőkkel és kvantitatív kutatásuk ügyfelekkel szintén alacsony CSR érzékenységet mutatott a fogyasztóknál. Míg a CSR kedvezően hat a fogyasztói attitüdökre és magatartásra elméletben, a CSR nem bizonyította hatékonyságát a piacon. WANG és ANDERSON (2011) is megállapítja, hogy a CSR tevékenységek és a fogyasztási szándékok nincsenek egymással közvetlen kapcsolatban. Wang megjegyzi, hogy sok fogyasztó igényli a vállalatok CSR tevékenységeinek kommunikációját, a CSR tevékenységet végző vállalatok pedig a CSR kommunikációját felhasználják vállalati imidzs és márka építésére is. Mindezek eredményeként a vállalatok CSR kommunikációja fontos szerepet játszik a fogyasztói attitűdök formálásában és a vállalati CSR tevékenységek és azok kommunikációjának értékelése vonatkozásában.

\subsection{Néhány kapcsolódó magyarországi kutatási eredmény - Some Relevant Hungarian Research Results}

Főiskolai és egyetemi hallgatók körében végzett 2010. évi kérdőíves felmérés eredményeiből kiderül, hogy mely információk fontosak a válaszadók számára élelmiszervásárláskor. Megadták a következő szempontokat: ár, származási hely, összetétel, minőségmegőrzési idő, gyártó. A válaszadóknak 1-től 5-ig terjedő skálán (ahol 5 a legfontosabb, 1 a legkevésbé fontos szempontot jelenti) kellett megjelölniük, hogy az egyes felsorolt szempontok milyen fontossággal bírnak a termék kiválasztása során. Az átlagértékek azt mutatják, hogy a legfontosabbnak az árat tartják $(4,29)$, ezt követi a minőségmegőrzési idő (4,11), majd az élelmiszerek összetétele $(3,94)$, végül a származási hely $(3,31)$ és legutolsó sorban a gyártó ismerete $(3,12)$ (CSAPÓNÉ és ÁRVÁNÉ, 2011).

Európában több országra jellemző a helyi élelmiszerek tudatos keresése. Magyarországon az uniós csatlakozás előtti időkig magas 
volt a hazai élelmiszerek részesedése, 2003ban például 90\%. A szabad kereskedelem azonban meghozta a tömeges importot, s a kereskedők a gyengébb magyar vásárlóerő miatt az olcsó, ezért alacsonyabb minőségű külföldi termékekkel keltek versenyre vevőikért. Az Új Magyarország Vidékfejlesztési Program Irányító Hatósága megbízásából 2011-ben készített felmérés szerint a megkérdezettek közel 80\%-a megnézi a csomagoláson a termék származását, háromnegyedük pedig tudatosan figyel arra, hogy magyar terméket vásároljon. A felmérésből kiderült, hogy egyre inkább, a megelőző évhez képest közel 40\%-kal többen figyelnek arra, hogy magyar terméket vásároljanak. A hazai áru megvásárlása mellett leggyakrabban felsorakoztatott érvek: a helyi vagy magyar termék vásárlásával hazai munkahelyek megtartását, új munkalehetőség kialakítását és ezáltal a helyi gazdaságot erősítjük, a szállítási távolság csökkenése pedig jelentős környezetvédelmi előnnyel jár (CZAUNER, 2011a).

A GfK Hungária Piackutató Intézet és az Ipsos Zrt. 2011. évi felmérése szerint élelmiszervásárlásnál a megkérdezettek 68\%-a számára fontos, hogy a termék magyar eredetű legyen, ami jelentős növekedést mutat a 2005ben mért 52 százalékhoz képest (CZAUNER, 2011b).

A Magyar Gallup Intézet 2005-ben felmérést végzett az etikus fogyasztói attitűdökről. Megkérdezték válaszadóikat, hogy a vállalatok tevékenységének melyek azok a területei, amelyekről fontos lenne tudniuk a vásárlóknak, amikről tájékoztatni kellene őket. A pozitív és negatív példák fontosságára külön-külön kérdésben kérdeztek rá. Fontossági sorrendben ezek a válaszok születtek a pozitív, jutalmazandó vállalati magatartással kapcsolatosan: (1) Magyarországon termel, (2) környezetvédelmi programot valósít meg, (3) támogatja hátrányos helyzetűek alkalmazását, (4) átlagon felül is jól bánik alkalmazottaival, (5) tulajdonosai magyarok, (6) jótékony, karitatív célokra adományokat oszt, (7) támogatja a helyi közösségek fejlesztését, (8) támogatja a kultúrát, (9) nem folytat állatkísérleteket.

A társadalmi, környezeti szempontból káros, etikátlan vállalati magatartással kapcsolatban az alábbi fontossági sorrend alakult ki: (1) fogyasztókat megtévesztő reklámfogásokat használ, (2) szennyezi a környezetet, (3) gyermekmunkát alkalmaz, (4) megalázó munkakörülmények között dolgoztat, (5) gyártását kitelepíti Magyarországról, (6) korrupcióban vesz részt, (7) a fejlődő országokban embertelen körülmények között vagy éhbérért dolgoztat, (8) nem fizeti be az adókat, (9) kozmetikai célú állatkísérleteket alkalmaz stb. A felmérésből kiderül még, hogy a magyar fogyasztók közel fele, 47\%-a úgy véli, hogy vásárlói döntésével képes befolyásolni a vállalatokat. 35-44\%-uk hajlandó többet fizetni egy termékért, ha az magyar termék vagy gyártójának tulajdonosai magyarok, illetve ha a termék vásárlása jótékony, karitatív célokat támogat. 38-46\%-uk akkor is bojkottálná a környezetszennyező, gyermekmunkát alkalmazó vagy gyártását kitelepítő vállalatok termékeit, ha azok helyettesítő terméke drágább lenne.

Megkérdezték válaszadóiktól azt, hogy befolyásolhatják-e a fogyasztók a vállalatok társadalmi és környezeti teljesítményét. A „nem ért egyet” és „egyáltalán nem ért egyet” választ adókat tovább kérdezték, hogy mi az oka egyet nem értésüknek. Közülük a legtöbben $(39,8 \%)$ úgy tartják, hogy a vállalatok csak akkor veszik figyelembe a vásárlói igényeket, ha ahhoz pénzügyi és profit érdekeik is kapcsolódnak. Valamivel több mint egynegyedük (27\%) szerint lehetséges, hogy a vállalatok figyelembe vennék a fogyasztók környezeti és társadalmi elvárásait, de kevesen vannak az elkötelezett fogyasztók: a többség inkább az ár, a minőség vagy a márka miatt választ, nem etikai vagy környezeti szempontok alapján. A válaszadók 25,8\%-a szerint lehetséges, hogy a vállalatok manipulálják és félrevezetik a fogyasztóikat, miközben látszólag igyekeznek megfelelni a társadalmilag és környezetileg felelős magatartásra vonatkozó fogyasztói elvárásoknak (MAGYAR GALLUP INTÉZET, 2005).

A Budapesti Corvinus Egyetem hallgatói körében végzett felmérés szerint a pozitív megkülönböztetés sokkal inkább jellemző a megkérdezett egyetemi hallgatók körében, mint a negatív megkülönböztetés, azaz a bojkott. Amíg a válaszadók csaknem kétharmada választott már azért egy terméket, márkát, mert annak gyártójáról jót hallott, addig csupán egyharmadukkal fordult elő, hogy azért nem vettek meg egy terméket, mert rosszat hallottak a 
gyártóról. A válaszadók 61\%-a választaná a drágább terméket, amelynek felelősebb a gyártója. Csupán 17,6\% venné le a polcról az olcsóbb, de kevésbé felelős terméket. További $16,3 \%$ pedig bizonytalan, szerintük mindegy, hogy melyik terméket vásárolnák meg (LUKÁCS, 2006).

\section{ANYAg ÉS MÓDSZER - MATERIAL AND METHOD}

Az országos kérdőíves felmérést 2014. március 1. és 2014. március 31. között végeztük el 1000 fogyasztó bevonásával. A mintavétel során az egyes régiók és településtípusok esetében eleve biztosítottuk a reprezentativitást, így azok szerkezete a KSH által előzetesen megállapított kvótának teljes mértékben megfelelt (kvótás mintavétel). Az egyes régiókban és a kijelölt településeken az ún. véletlen séta elvét alkalmaztuk, amely teljes véletlenszerüséget biztosít a megfelelő válaszadók kiválasztásához (azaz minden egyes személynek azonos esélyt adtunk a mintába kerülésre). A módszer lényege, hogy minden kérdezőbiztos az előre kiválasztott régióban és településen induló címeket kapott (a hazai régiók és településtípusok a lakosság létszám-arányainak megfelelően kerültek a mintába). A kiindulási címtől indulva - a házszámok szerint növekvő sorrendben az utca ugyanazon oldalán a harmadik háznál kezdték el a kérdezőbiztosok a kérdezést, majd ha itt végeztek, a következő harmadik háznál folytatták azt. A mintavételi terv összeállítása során arra is ügyeltünk, hogy a kérdezők számára ne okozzon fejtörést az sem, ha éppen egy családi házas körzetben, avagy emeletes házak környékén járnak. A felkeresett háztartás lakói közül az ún. születésnapi kulcs alkalmazásával választottuk ki az interjúra megfelelő személyt. A módszer lényege, hogy a megkérdezés során arra kérdezett rá az interjút lefolytató kérdezőbiztos, hogy a családtagok közül hány 18 éves és annál idősebb személy lakik a háztartásban. Második lépésként a megfelelő korú személyek közül az a fogyasztó került kiválasztásra, akinek a születési dátuma (születésnapja) a legközelebb esett a megkérdezés napjához. Ezzel a módszerrel második lépésben is biztosítottuk a teljes véletlenszerüséget. A minta véletlen hibája $\pm 1,9 \%-3,2 \%$. Végezetül a repre- zentativitás biztosítása érdekében a mintát ún. többdimenziós súlyozással (nem és kor szerint) korrigáltuk, így a minta négy tényező (régió, településtípus, nem, kor) alapján tükrözi az alapsokaság összetételét. Statisztikai módszerek közül Kruskall-Wallis tesztet és leíró statisztikai módszereket használtunk. A páronkénti összehasonlítást Mann-Whitney U próbával végeztük.

\section{EREDMÉNYEK - RESUltS}

Első kérdésünk arra keresett választ, hogy a fogyasztók mit gondolnak, mit foglal magában az a kifejezés, hogy „vállalatok társadalmi felelősségvállalása”. Felajánlottunk alternatívákat: (1) törvények, szabályok betartása; (2) környezetvédelem szem előtt tartása, környezettudatos/ fenntartható müködés, (3) munkahelyteremtés és foglalkoztatás, (4) múvészetek, kultúra, sportélet támogatása, (5) alapítványok létrehozása, támogatása, (6) alkalmazottak számára egészséges, kiegyensúlyozott munkakörnyezet biztosítása, (7) etikus bánásmód valamennyi üzleti partnerrel, (8) ügyes marketingfogás, (9) tisztességes kommunikáció, bánásmód a fogyasztók irányába, (10) felelősség a társadalmi és természeti környezet iránt. Mindegyik válasz esetében a CSR-rel való kapcsolat erősségét kellett meghatározni 1-5 Likert skálán, ahol az 5 a legerősebb kapcsolatot, az 1 a leggyengébb kapcsolatot jelentette.

Megnéztük a válaszok értékének az átlagát illetve a szórását. Kijelenthetjük, hogy a CSR és az egyes fogalmak kapcsolatának erőssége egy esetet kivéve (ügyes marketingfogás 3,88) 4 feletti értékkel rendelkezik. A legjobban a válaszadók szerint a munkahelyteremtés és foglalkoztatás $(4,662)$, majd a törvények, szabályok betartása $(4,635)$ és a környezettudatos/ fenntartható múködés $(4,624)$ kapcsolódik a CSR-hez. Ugyanebbe a csoportba sorolhatjuk még a felelősség a társadalmi és természeti környezet iránt kategóriát is, hiszen az átlaga 4,57. A magas átlagok mellett a szórás értékei ezeknél a legkisebbek, azaz a vélemények ezekben az esetekben a legegységesebbek.

Ezután a kapott eredményeket külön-külön iskolai végzettség, jogállás és anyagi helyzet alapján is csoportosítottuk, majd levontuk a 
következtetéseket. A csoportosítás során találtunk szignifikáns eltéréseket.

$\mathrm{Az}$ anyagi helyzetre vonatkozóan érdekes megállapításra jutottunk. Az anyagi helyzet nem befolyásolja a megítélését az egyes megállapításoknak $(\mathrm{P}>0,05)$.

Az iskolázottság szerinti csoportosítás szerint az érettségivel rendelkezők szerint a törvények, szabályok betartása nem része a CSR-nek $(\mathrm{P}=0,04)$. Ez a vállalatok második felelőssége a gazdasági felelősség után: betartani a törvényt (ezt nevezzük jogi felelősségnek) (GYŐRI, 2010). Ezen válaszadók számára a CSR ezek után következik. Az egészséges, kiegyensúlyozott munkakörnyezet biztosítása mindegyik iskolázottsági szint szerint része a CSR-nek $(\mathrm{P}=0,909)$. A művészetek, kultúra, sportélet támogatása a diplomás csoporton kívül mindegyik csoport szerint a CSR része $(\mathrm{P}=0,039)$. Vélhetően a diplomások jobban informáltak és ők a CSR-t inkább közös értékteremtésként értelmezik. A szponzoráció kétségtelenül rendkívül fontos, de nem egyértelműen a közös értékteremtésről szól.

Jogállás alapján a törvények, szabályok betartása nem része egy vállalat CSR-jének a munkahelyen nem dolgozó csoport szerint. A diákok szerint a CSR csak egy ügyes marketingfogás $(\mathrm{P}=0,035)$. Miután ők jelentik a vállalatok számára a jövő fogyasztóit, megfelelő üzleti etikai vagy CSR kurzusokkal lehet javítani hozzáállásukon. A CSR nem lehet csak marketing eszköz (annak ellenére sem, hogy néhány vállalat számára az).

További kérdésekkel vizsgáltuk azt is, hogy egy-egy cég múködéséről kiderülő negatív vagy pozitív információk mennyire befolyásolják a megkérdezetteket a cég által előállított/forgalmazott termék/szolgáltatás vásárlásakor (1. táblázat). A következőkben felsorolt pozitív és negatív információkat 1-5 skálán kellett értékelniük a válaszadóknak. tak:

A negatív információk a következők vol-

1. Korrupt múködés.

2. Nem viselkedik korrekt módon beszállítóival.

3. Állatkísérleteket alkalmaz, amikor el is kerülhetné.

4. Nem fizet adókat.

5. Nem foglalkozik az emberi jogokkal.
6. Nem viselkedik korrekt módon versenytársaival.

7. Fogyasztómegtévesztő reklámokat alkalmaz.

8. Környezetszennyezően müködik.

9. Gyermekmunkát alkalmaz.

10. Pazarolja a természeti erőforrásokat.

11. Alkalmazottai nincsenek bejelentve.

12. Fejlődő országokban „munkásnyúzdákban" dolgoztat.

13. Bezárja magyarországi üzemét/üzemeit.

14. Termékei/szolgáltatásai egészségkárosítóak.

15. A termék/szolgáltatásismertetők félrevezetőek, nem teljes körúek.

A pozitív információk a következők voltak:

1. Energiatakarékosságra ösztönöz.

2. Megfelelő munkakörnyezet biztosítása.

3. Munkahelyteremtés Magyarországon.

4. Diszkrimináció elutasítása.

5. Önkéntes munkavégzés mint támogatás.

6. Környezettudatos, fenntartható múködés.

7. Sportélet támogatása.

8. Alapítványok, segélyszervezetek támogatása.

9. Oktatás támogatása.

10. Tisztességes, etikus múködés.

11. Díjakkal tüntették ki felelős üzleti magatartásáért.

12. Művészet és kultúra támogatása.

13. Beszámolókat tesz közre társadalmilag/ környezetileg felelős magatartásáról.

14. Magyarországon múködik és fizet adót.

15. Gyakran hallok, olvasok felelős üzleti magatartásukról. Arra voltunk kíváncsiak, hogy az egyes csoportosításokban vannak-e érzékelhető különbségek a csoportok között. 


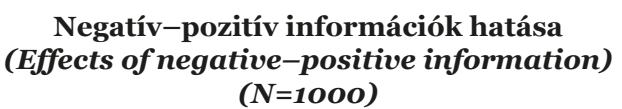

\begin{tabular}{|c|c|c|}
\hline \multirow{2}{*}{$\begin{array}{l}\text { Negatív-pozitív információk } \\
\text { (Negative-Positive Information) }\end{array}$} & \multicolumn{2}{|c|}{$\begin{array}{l}\text { Szignifikancia-szint } \\
\text { (Level of Significance) }\end{array}$} \\
\hline & $\begin{array}{c}\text { Iskolai végzettség } \\
\text { (Level of } \\
\text { Education) }\end{array}$ & $\begin{array}{c}\text { Jogállás } \\
\text { (Legal } \\
\text { Status) }\end{array}$ \\
\hline Korrupt módon múködik (Corrupt operation) & 0,035 & 0,043 \\
\hline $\begin{array}{l}\text { Nem viselkedik tisztességesen beszállítóival } \\
\text { (Incorrect business behaviour with suppliers) }\end{array}$ & 0,175 & 0,038 \\
\hline $\begin{array}{l}\text { Állatkísérleteket alkalmaz, amikor el is kerülhetné } \\
\text { (Unnecessary animal testing) }\end{array}$ & 0,019 & 0,297 \\
\hline $\begin{array}{l}\text { Nem foglalkozik az emberi jogokkal } \\
\text { (Does not deal with human rights) }\end{array}$ & 0,173 & 0,095 \\
\hline Környezetszennyezően múködik (Pollutes the environment) & 0,023 & 0,045 \\
\hline $\begin{array}{l}\text { Gyermekmunkával összefüggésbe hozható tevékenysége } \\
\text { (Child labour-related activities) }\end{array}$ & 0,254 & 0,174 \\
\hline $\begin{array}{l}\text { Pazarolja a természeti erőforrásokat } \\
\text { (Waste of natural resources) }\end{array}$ & 0,000 & 0,046 \\
\hline $\begin{array}{l}\text { Fejlődő országokban embertelen körülmények között dolgoz- } \\
\text { tat (Inhuman working conditions in developing countries) }\end{array}$ & 0,255 & 0,353 \\
\hline $\begin{array}{l}\text { Bezárja magyarországi üzemét/üzemeit } \\
\text { (Closes its factory(ies) in Hungary) }\end{array}$ & 0,519 & 0,332 \\
\hline A diszkriminációt kerüli (Avoids discrimination) & 0,105 & 0,312 \\
\hline $\begin{array}{l}\text { Önkéntes munkavégzéssel támogat rászorulókat } \\
\text { (Voluntary work as support) }\end{array}$ & 0,399 & 0,132 \\
\hline $\begin{array}{l}\text { Környezettudatosan, fenntarthatóan múködik } \\
\text { (Environmentally friendly, sustainable operation) }\end{array}$ & 0,123 & 0,042 \\
\hline Sportéletet támogatja (Supports sports) & 0,563 & 0,252 \\
\hline $\begin{array}{l}\text { Alapítványokat, segélyszervezeteket támogat } \\
\text { (Supports foundations) }\end{array}$ & 0,396 & 0,305 \\
\hline Oktatást támogatja (Supports education) & 0,414 & 0,232 \\
\hline Tisztességesen, etikusan múködik (Fair, ethical operation) & 0,498 & 0,127 \\
\hline $\begin{array}{l}\text { Díjakkal tüntették ki felelős üzleti magatartásáért } \\
\text { (Prizes awarded for responsible business conduct) }\end{array}$ & 0,570 & 0,685 \\
\hline $\begin{array}{l}\text { Müvészeteket és a kultúrát támogatja } \\
\text { (Supports arts and culture) }\end{array}$ & 0,327 & 0,140 \\
\hline
\end{tabular}

Forrás (Source): Saját kutatás (Own research), 2014

Iskolai végzettség vonatkozásában (2. ábra) a legalább érettségivel rendelkezőknél a korrupt múködés jobban befolyásolja a termékválasztást. Általánosságban azonban elmondható, hogy minél magasabb az iskolai végzettség, mind a pozitív, mind a negatív információk egyre jobban befo- lyásolják a fogyasztói döntést azokban a kérdéskörökben, ahol a csoportok között szignifikáns eltérés megállapítható. Külön kiemelhető, hogy a gyermekmunkát mindegyik csoport elítéli. Emellett pozitív megítélést kapott minden csoporton belül az, ha alapítványokat, segélyszervezeteket támogat a vállalat. 


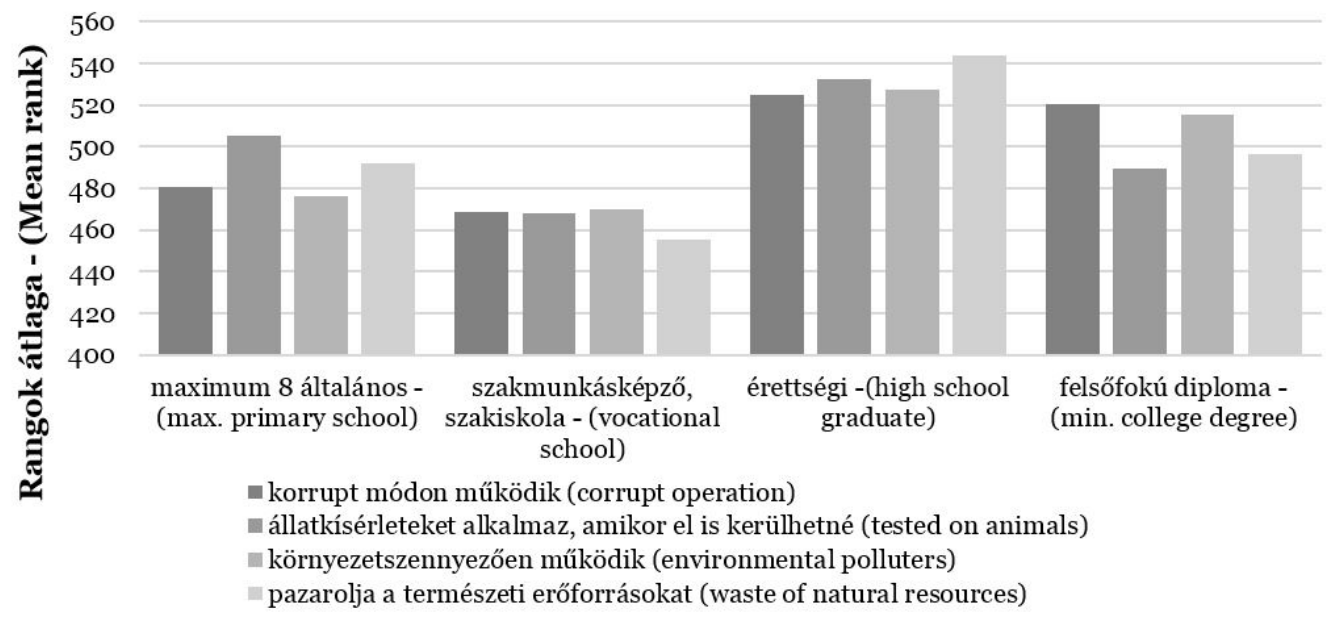

2. ÁBRA

Iskolai végzettség és a vállalatról hallott negatív információk közötti kapcsolat

FIG. 2 (Relation Between the Level of Education and Negative Information on Companies)

Forrás (Source): Saját kutatás (Own research), 2014

Pozitív információk hatása

(Effects of Positive Information)

$(\mathrm{N}=\mathbf{1 0 O O})$

TABLE 2

\begin{tabular}{|c|c|c|c|}
\hline \multicolumn{4}{|c|}{$(N=1000)$} \\
\hline $\begin{array}{l}\text { Pozitív információ } \\
\text { (Positive Information) }\end{array}$ & $\begin{array}{c}\text { Iskolai végzettség } \\
\text { szerinti } \\
\text { szignifikancia- } \\
\text { szint (Level of } \\
\text { Significance } \\
\text { Grouped by } \\
\text { Education) }\end{array}$ & $\begin{array}{l}\text { Átlag } \\
\text { (Mean) }\end{array}$ & $\begin{array}{l}\text { Szórás (Std. } \\
\text { Deviation) }\end{array}$ \\
\hline A diszkriminációt kerüli (Avoids discrimination) & 0,105 & 3,66 & 1,438 \\
\hline $\begin{array}{l}\text { Önkéntes munkavégzéssel támogat rászorulókat } \\
\text { (Voluntary work as support) }\end{array}$ & 0,399 & 3,45 & 1,385 \\
\hline $\begin{array}{l}\text { Környezettudatosan, fenntarthatóan múködik } \\
\text { (Environmentally friendly, sustainable operation) }\end{array}$ & 0,123 & 3,82 & 1,368 \\
\hline Sportéletet támogatja (Supports sports) & 0,563 & 3,49 & 1,375 \\
\hline $\begin{array}{l}\text { Alapítványokat, segélyszervezeteket támogat } \\
\text { (Supports foundations) }\end{array}$ & 0,396 & 3,45 & 1,365 \\
\hline Oktatást támogatja (Supports education) & 0,414 & 3,42 & 1,383 \\
\hline $\begin{array}{l}\text { Tisztességesen, etikusan működik } \\
\text { (Fair, ethical operation) }\end{array}$ & 0,498 & 3,97 & 1,333 \\
\hline $\begin{array}{l}\text { Díjakkal tüntették ki felelős üzleti magatartásáért } \\
\text { (Prizes awarded for responsible business conduct) }\end{array}$ & 0,570 & 3,46 & 1,419 \\
\hline $\begin{array}{l}\text { Múvészeteket és a kultúrát támogatja } \\
\text { (Supports arts and culture) }\end{array}$ & 0,327 & 3,35 & 1,355 \\
\hline
\end{tabular}

Forrás (Source): Saját kutatás (Own research), 2014 
Megállapítható továbbá, hogy a környezetszennyező múködés és az erőforrások pazarló felhasználása magasabb az érettségivel rendelkező vagy magasabb iskolai végzettségüek körében.

Látható, hogy a pozitív információk megítélésével kapcsolatosan az iskolai végzettség szerinti csoportosítás esetében nem állapítható meg szignifikáns különbség az egyes csoportok attitűdjei között (2. táblázat). Ugyanakkor megfigyelhető, hogy minden egyes kérdésnél az átlag 3,5 körül található, ami a középérték felett van és a szórás mindössze 1,4 körüli. Ebből azt a következtetést vonjuk le, hogy mindegyik kérdés fontos a vásárlás során, de nem kiemelkedően.

Ha a jogállás szerinti csoportosítást vizsgáljuk (3. ábra), akkor a következő megállapításokat tehetjük: A GYES-en, GYED-en lévőket és a háztartásbelieket jelentősen be- folyásolja, ha egy vállalat korrupt módon müködik ( $\mathrm{P}=0,043)$. Az összes csoportot egyaránt megérinti, ha egy céget gyermekmunka alkalmazásával hozzák összefüggésbe $(\mathrm{M}=3,83$, $\mathrm{D}=1,4)$. A háttérben a családban lévő gyermek(ek) kapcsán az együttérzés lehet (jogállás szerint a $\mathrm{P}=0,174)$. A környezetszennyezéssel összefüggő kérdések minden aktív csoportot egyaránt érintenek ( $\mathrm{P}=0,045$ és $\mathrm{P}=0,042)$. A munkakörülmények embertelen volta minden csoportot nagyon érint $(\mathrm{P}=0,353, \mathrm{M}=3,7$, $\mathrm{D}=1,39)$. Az elnyert kitüntetések, elismerések és a szükségtelen állatkísérletek használata a termékfejlesztéseknél, minden csoportot egyaránt közepesnél jobban befolyásol, de a szórás értéke minden esetben ( $\mathrm{M} \sim 3,4, \mathrm{D} \sim 1,6)$ elég magas, ami azt jelenti, hogy elég szélsőségesek a vélemények ebben a kérdéskörben, de behatárolni a fontosságát sem a jogállás, sem korcsoport $(\mathrm{P}>0,05)$ szerint nem sikerült.

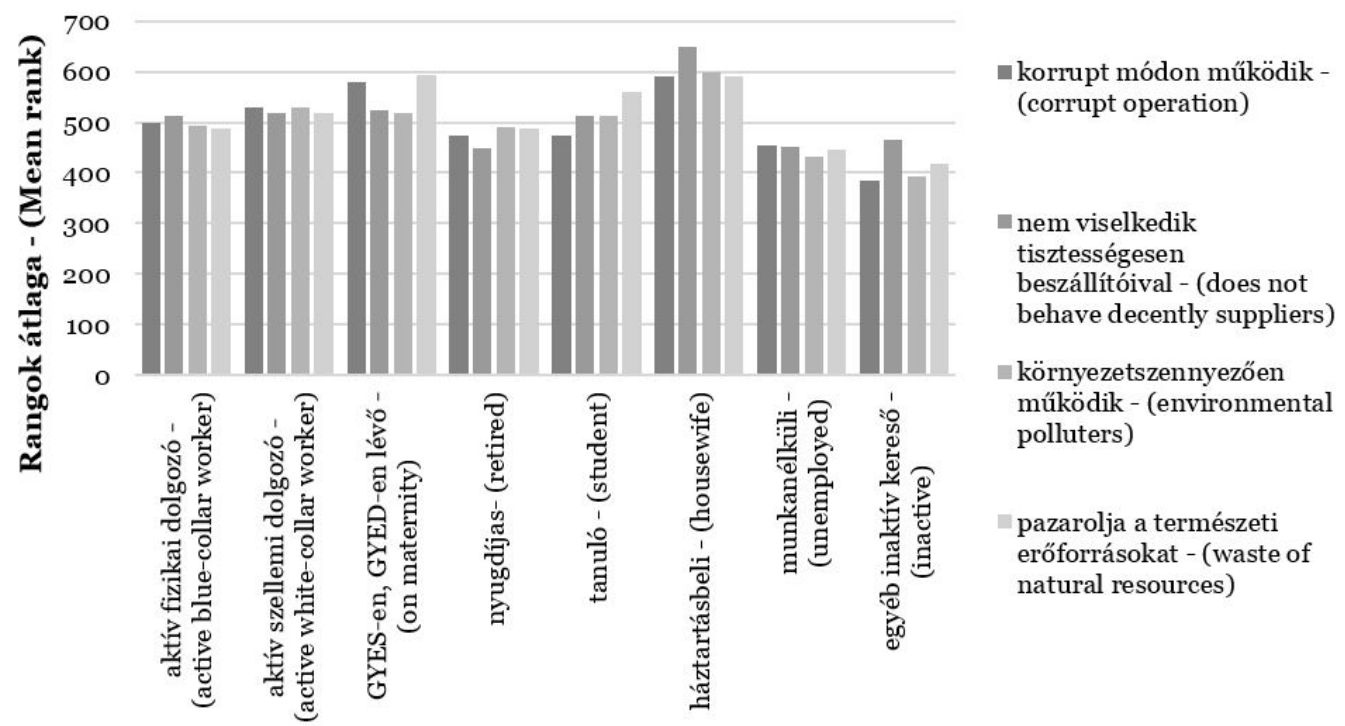

3. ÁBRA

A jogállás és a vállalatról hallott negatív információk közötti kapcsolat

FIG. 3 (Relation Between Legal Status and Negative Information on Companies)

Forrás (Source): Saját kutatás (Own research), 2014

Kutatásunk során vizsgáltuk azt is, hogy az általunk felsorolt szempontok milyen mértékben befolyásolják a fogyasztói döntést (3. táblázat): (1) a termék ára, (2) a termék gyártója, (3) a termék előállítási helye, (4) a termék összetétele, (5) a termékkel járó környezetterhelés, (6) a termék biztonságossá- ga, (7) a termék egészségessége, (8) a termék csomagolása, megjelenése, (9) ár-érték arány, (10) lejárati idő. 1-től 5-ig terjedő skálán kellett a megkérdezetteknek értékelni az egyes szempontok fontosságát termékválasztáskor. Az 5 jelenti: leginkább befolyásol és az 1 jelentése: legkevésbé befolyásol. 
Befolyásoló szempontok

(Influencing Factors) (N=1OOO)

\begin{tabular}{lcccc}
\hline \multicolumn{1}{c}{ Befolyásoló szempont (Influencing Factor) } & Min. & Max. & $\begin{array}{c}\text { Átlag } \\
\text { (Mean) }\end{array}$ & $\begin{array}{c}\text { Szórás } \\
\text { (Std. Deviation) }\end{array}$ \\
\hline Ár (Price) & $\mathrm{O}$ & 5 & 4,74 & 0,680 \\
\hline Gyártó (Producer) & $\mathrm{O}$ & 5 & 3,83 & $\mathbf{1 , 1 0 1}$ \\
\hline Előállítási hely (Place of production) & $\mathrm{O}$ & 5 & 3,83 & $\mathbf{1 , 1 3 7}$ \\
\hline Összetétel (Ingredients) & $\mathrm{O}$ & 5 & 4,44 & 0,833 \\
\hline Környezetterhelés (Environmental impact) & $\mathrm{O}$ & 5 & 3,61 & 1,283 \\
\hline Biztonságosság (Product safety) & $\mathrm{O}$ & 5 & 4,58 & 0,790 \\
\hline Egészségesség (Healthiness) & $\mathbf{1}$ & 5 & 4,58 & 0,755 \\
\hline Megjelenés (Product outfit) & $\mathrm{O}$ & 5 & 4,06 & 0,932 \\
\hline Ár-érték arány (Price-value ratio) & $\mathrm{O}$ & 5 & 4,71 & 0,637 \\
\hline Lejárati idő (Shelf life time) & $\mathrm{O}$ & 5 & 4,65 & 0,700 \\
\hline
\end{tabular}

Forrás (Source): Saját kutatás (Own research), 2014

A kérdésre adott válaszok elemzéséből kiderül, hogy az adott átlagértékek 4,3 körüliek, a szórásaik is mindössze 0,8 körüliek. A legmagasabb átlagokat az árra, ár-érték arányra és a lejárati időre kaptunk. Az ár és ár-érték arány szempontokra adott válaszok 4,71-es átlagot értek el nagyon alacsony szórásértékek mellett. Ez azt jelenti, hogy a magyar piac rendkívül árérzékeny. A lejárati időre kapott magas átlag azt jelenti, hogy ez egy nagyon fontos szempont. A termék biztonságossága $(4,58)$, összetétele $(4,44)$, egészségessége $(4,58)$ sokkal kisebb értéket kapott, amit értelmezhetünk úgy is, hogy nehezebben megtalálható adatok, de úgy is, hogy az árral kapcsolatos érzékenység elnyomja az utóbbi jellemzőket. Külön megjegyeznénk, hogy a környezetterheléssel $(3,61)$ és a gyártóval $(3,83)$ kapcsolatos információk jóval kisebb mértékben befolyásolják a fogyasztókat, mint a fentiek közül bármelyik.

Vizsgáltuk a háttérváltozókat is és összefüggéseket kerestünk az egyes demográfiai változók és a kapott válaszok között. Szignifikáns eltérést találtunk az iskolai végzettségre vonatkozóan az ár $(\mathrm{P}=0,007)$, a gyártó $(\mathrm{P}=0,015)$, az előállítás helye $(\mathrm{P}=0,04)$, a termék összetétele $(\mathrm{P}=0,029)$ és megjelenése $(\mathrm{P}=0,001)$ szerint is. Minél magasabb az iskolai végzettség, a gyártó neve annál fontosabb. Ugyanezt állapíthatjuk meg az előállítás helyével kapcsolatban is. Feltételezhető, hogy a magasabb iskolai vég- zettségűek tájékozottabbak a vállalatok felelősségéről. Érdekli őket az előállító vállalat felelős vagy éppen felelőtlen üzleti magatartása. Az előállítási hely vonatkozásában vélhetően egyértelmű számukra, hogy hazai termékek preferálásával a hazai gazdaság fejlődéséhez járulnak hozzá. Számukra - a többi vizsgált csoporthoz képest - a legkevésbé fontos az ár, valamint a termék megjelenése. Ezen két-két szempont alacsonyabb szintű fontossága talán magyarázható azzal is, hogy iskolázottságukból adódóan vélhetően jobb anyagi körülmények között élnek, így megtehetik, hogy a termék árát hátrébb rangsorolják a vásárlást befolyásoló szempontok között. A termék összetétele kapcsán a legalacsonyabb iskolai végzettségüeket kell megemlítenünk, miután náluk volt ez a legkevésbé fontos. A kiemelt öt szempont közül náluk az ár kiugróan magas rangot kapott. Ezzel magyarázhatóak vélhetően szerényebb anyagi körülményeik.

A családi jogállás vonatkozásában jóval kevesebb megállapítást tudunk leszürni. A vizsgált tíz szempont közül a termék előállítási helyére $(\mathrm{P}=0,024)$ és a lejárati időre vonatkozóan $(\mathrm{P}=0,026)$ találtunk csak szignifikáns eltérést. A nőtlen, hajadon (jellemzően fiatal) válaszadókat a lejárati idő nem igazán befolyásolja a vásárlásban. A többi csoportnál ennek a szempontnak a rangja jóval nagyobb. A termék előállítási helye a házasok és az özvegyek szá- 
mára fontosabb. Ők jellemzően az idősebb korosztályba tartoznak. Róluk elmondható még az is, hogy a lejárati idő is közel olyan fontossággal bír fogyasztói döntésükben mint az előállítás helye. A házasok vonatkozásában vélhetően a család iránti felelősség áll a háttérben.

A válaszadók jogállásának elemzésekor a termék árával $(\mathrm{P}=0,01)$, előállítás helyével $(\mathrm{P}=0,011)$ és ár-érték aránnyal $(\mathrm{P}=0,026)$ öszszefüggésben találtunk szignifikáns eltérést. A szellemi dolgozókat és a tanulókat kevésbé befolyásolja az ár, ami az első csoport esetében a munkájukkal összefüggésben vélhetően a magasabb jövedelmi helyzettel magyarázható. A tanulók még önálló keresettel nem rendelkeznek, nem a „saját” pénzüket költik és talán nem is tájékozottak még a tudatos/felelős fogyasztás egyéb szempontjairól. Azonban a diákok az egyik legfontosabb csoport, mivel ők lesznek a közeljövő „teljes értékü” fogyasztói. Megfelelő oktatással be lehet vonni óket a tudatos vásárlók körébe. Az inaktív keresők, egyéb eltartottak és a háztartásbeliek csoportjánál az ár igen fontos tényező, ami egyértelmüen a szerényebb anyagi helyzettel magyarázható. A termék előállításának a helye az egyéb eltartottak számára meglehetősen kis jelentőséggel bír. Az ár a legfontosabb szempont számukra a vizsgált szempontok közül, az ár-érték arány pedig még a megjelenésnél is jóval jelentéktelenebb szempont számukra. Az ő esetükben ezek az eredmények egyértelműen a jövedelem hiányával magyarázhatók.

Utolsó vizsgált feltételünk a család jövedelmi helyzetével volt kapcsolatos. Kétségtelen, hogy a jövedelmi helyzet romlásával egyre fontosabb szempont a termék ára. A termék elöállítási helye $(\mathrm{P}=0,038)$ és gyártója $(\mathrm{P}=0,025)$ ugyanebben az irányban egyértelműen csökkenő jelentőséggel bír. A termék egészségessége $(\mathrm{P}=\mathrm{O}, 028)$, megjelenése $(\mathrm{P}=\mathrm{O}, 01)$, ár-érték aránya $(\mathrm{P}=0,01)$, és a lejárati idő $(\mathrm{P}=0,01)$ érdekes módon a „középső” kategóriánál (éppen elegendő, hogy megéljenek belőle, de félretenni már nem tudnak) jelennek meg legfontosabb szempontként.

\section{KöVETKEZTETÉSEK ÉS}

\section{JAVASLATOK - CONCLUSIONS AND \\ SugGESTIONS}

Eredményeink alátámasztják a CSR jelenlegi gyakorlatát a CSR definiálásával kapcsolatosan. A felsorolt alternatívák szinte mindegyike szoros kapcsolatban áll a CSR-el a válaszadók szerint. A „munkahelyteremtés és foglalkoztatás"-ra kapott legnagyobb átlagérték jelzi ennek a tevékenységnek a fontosságát. Ez magyarázható azzal is, hogy - legalábbis Magyarországon - a CSR napjainkban leginkább a felelős foglalkoztatással kapcsolódik össze. CSR-ről szóló tanulmányokban, illetve vállalatok CSR programjainak ismertetőiben olvashatjuk, hogy a vállalatok CSR költségvetéseinek körülbelül háromnegyedét általában az alkalmazottakat megcélzó programokra fordítják. Jó látni, hogy a CSR-t nem tekinti szimplán marketingfogásnak a válaszadók zöme, csak a diákok. Ezen a véleményen a CSR korrekt, teljes körü oktatásával lehet „változtatni”. A vásárlói döntést befolyásoló szempontokat vizsgálva eredményeink megerősítik az ár és az ár-érték arány fontosságát. A gyártó és felelős üzleti gyakorlata kevésbé fontos információ a legtöbb válaszadó számára, bár a vizsgált csoportok különböző mértékben odafigyelnek a vállalatokról kapott/hallott pozitív, illetve negatív információkra.

\section{5. ÖSSZEFOGLALÁs - SUMMARY}

A vállalatok társadalmi felelősségvállalása (CSR) igen gyakori téma napjainkban mind hazai, mind nemzetközi szinten. A profitmaximalizálás természetes a vállalatok számára, de gazdasági tevékenységük végzése közben nem lenne szabad elfelejtkezniük tevékenységük velejáró társadalmi és környezeti hatásairól sem. Ki kell itt még emelnünk a napjainkban szintén gyakran szóba kerülő fenntarthatóság kérdését is. A vállalatoknak is felelőssége a Föld, természeti erőforrásaink és a jövő generációk sorsa. 
Sok vállalatban belső indíttatásra ki is alakult ez a fajta felelősségérzet és példaértékü CSR, illetve fenntarthatósági lépéseket tesz. Napjainkban már a társadalom részéról is erős nyomás nehezedik, komoly elvárás fogalmazódik meg a vállalatok irányába a felelős múködés iránt. Ennek a hatásnak is köszönhető a felelősen múködő vállalatok számának gyarapodása.

De mit is értünk CSR alatt? Milyen tevékenységek, lépések sorolhatók ide? Milyen indíttatásból dolgoznak ki a vállalatok CSR stratégiát, CSR programokat, készítenek CSR vagy fenntarthatósági jelentéseket? Mi húzódhat meg a háttérben? Számos tanulmány foglalkozik a CSR motivációival, melyek között a vállalat megítélése, imidzse, „bennünket fognak preferálni a fogyasztók" is igen gyakran megjelenik. Értékelik-e azonban a vállalatok CSR lépéseit a fogyasztók? Számos kutató arra az eredményre jutott, hogy nem. Általában véve igen fontos elvárás részükről a felelős üzleti magatartás, de amikor ténylegesen döntenek egy termék megvásárlásáról, ez a szempont igencsak hátra rangsorolódik.

Tanulmányunk célja számba venni, hogy a megkérdezett magyar fogyasztók mit tudnak a CSR-ről, mivel azonosítják a CSR-t, milyen információk alapján hozzák meg fogyasztói döntésüket, és összefüggéseket keresni a kapott eredmények és a minta demográfiai változói között. Mindezt primer kutatásunk eredményei alapján tesszük meg. Kutatási eredményeink összhangban vannak a CSR általános értelmezésével. Csaknem az összes felsorolt alternatívát a CSR fogalomköréhez társították a megkérdezett fogyasztók. A legmagasabb átlagértéket a „munkahelyteremtés, foglalkoztatás” alternatíva kapta, ami jelzi ezen tevékenység kiemelt jelentőségét. A fogyasztói döntést befolyásoló tényezók vonatkozásában kutatási eredményeink az „ár” és az „ár-érték arány” elsődlegességét támasztották alá. Ezen kutatási eredményünk összhangban áll számos kutatási eredménnyel, miszerint a fogyasztók számára csak elvben fontos a termék gyártója és annak felelős üzleti magatartása, a tényleges fogyasztói döntésekben sajnos már nem jelenik meg ez az elvárás.

\section{IRODALOMJEGYZÉK - REFERENCES}

Czauner P.: Egy kis hazai. In: Trade Magazin, 2011a. 4 (5) 18-21.

Czauner P.: Értékesebb a hazai élelmiszer tanítani fogják a magyar ízeket. In: Trade Magazin, 2011b. 4 (1-9) 22-25.

Csapóné R. T. - Árváné V. G.: Tudatos fogyasztói szokások felmérése egyetemi és főiskolai hallgatók körében. Útkeresés és növekedés. BGF Tudományos évkönyv. Budapest, 2011.

Doane, D.: The Myth of CSR. In: Stanford Social Innovation Review, 2005. Fall. 2329.

Epstein-Reeves, J.: So You Call This CSR? Or One of Its Many Other Names? 2011. URL: http://www.forbes.com/sites/ csr/2011/07/28/so-you-call-this-csr-orone-of-its-many-other-names/ (Letöltés dátuma: 2015. Ápr. 10.)

Győri Zs.: CSR-on innen és túl. PhD értekezés. Budapesti Corvinus Egyetem Gazdálkodástani Doktori Iskola. Budapest, 2010.

Győri Zs.: Vállalati felelősség - felelős vállalkozások. 55th Georgikon Scientific Days, Keszthely, Hungary, 26-27 Sept. 2013. 178-188.

Kim, S.: Transferring Effects of CSR Strategy on Consumer Responses: The Synergistic Model of Corporate Communication Strategy. In: Journal of Public Relations Research, 2011. 23 (2) 218-241.

Lukács R.: Fenntartható fejlődés és tudatos fogyasztók. Mit tudnak a fiatalok a felelős fogyasztásról? Magyar Marketing Szövetség - Marketing Oktatók Klubjának 12. Országos Konferenciája. Budapest, 2006. aug. 24-25.

Magyar Gallup Intézet: Etikus fogyasztói attitűdök Magyarországon. 2005. 1-16.

NBS: Socially conscious consumerism. 2015. http://nbs.net/wp-content/uploads/ NBS-Consumerism-Primer.pdf (Letöltés dátuma: 2015. ápr. 11.) 
Öberseder, M. - Schlegelmilch, B. B., Gruber, V.: "Why Don't Consumers Care About CSR?": A Qualitative Study Exploring the Role of CSR in Consumption Decisions. In: Journal of Business Ethics. 2011. 104 (4) 449-460.

Pomering, A. - Dolnicar, S.: Assessing the Prerequisite of Successful CSR Implementation: Are Consumers Aware of CSR Initiatives? In: Journal of Business Ethics. 2009. 85 (2 Suppl.) 285-301.
Schwartz, M. S. - Saiia, D.: Should Firms Go "Beyond Profits"? Milton Friedman versus Broad CSR. In: Business and Society Review. 2012. 117 (1) 1-31.

Wang, A. - Anderson, R. B.: A MultiStaged Model of Consumer Responses to CSR Communications. In: Journal of Corporate Citizenship. 2011. 41 (SpringMarch), 51-68.

\section{JEGYZETEK $*$ NOTES}


JEGYZETEK $\nRightarrow$ NOTES 